\title{
Sources and application methods of boron in Eucalyptus crop
}

\section{Fontes e modos de aplicação de boro na cultura do eucalipto}

\author{
Thiago de Souza Celestrino ${ }^{1 *}$; Salatiér Buzetti²; Marcelo Carvalho Minhoto \\ Teixeira Filho ${ }^{2}$; Rodolfo de Niro Gazola ${ }^{1}$; Raíssa Pereira Dinalli1; Paulo Henrique \\ Müller da Silva ${ }^{3}$; Ariádne Carla de Carvalho ${ }^{4}$; Guilherme Defavari Sarto ${ }^{4}$
}

\begin{abstract}
Cerrado soils have low boron (B) content, making supplementation of this element through fertilization via soil and/or leaf is a common practice. It is therefore important to establish the best mode of application and source of B for the proper development of eucalyptus. Thus, the objective of this study was to compare the effect of B sources with high and low solubility on eucalyptus cultivation and to examine the effect of foliar application of the micronutrient. The experiment was conducted in an area located at $20^{\circ} 34^{\prime} \mathrm{S}$ latitude and $51^{\circ} 50^{\prime} \mathrm{W}$ longitude with an altitude of $305 \mathrm{~m}$ during the period from January 2012 to February 2014. The experiment was set up using a randomised complete block design with six treatments and five replications, in a $3 \times 2$ factorial scheme, consisting of $0 \mathrm{~kg} \mathrm{ha}^{-1} \mathrm{of} \mathrm{B}, 1 \mathrm{~kg}$ $\mathrm{ha}^{-1}$ of B using boric acid as a source (high solubility, 17\% B) or $1 \mathrm{~kg} \mathrm{ha}^{-1}$ of B using borogran as a source (low solubility, $10 \% \mathrm{~B}$ ), applied to the planting furrow, with or without foliar application of $0.5 \%$ boric acid in a solution with a volume of $250 \mathrm{~L} \mathrm{ha}^{-1}$. Except for the case of foliar B application, there was an increase in plant height in treatments that received the micronutrient at planting, which differed significantly from the control. However, both sources, independent of solubility, exhibited similar results. The two foliar B applications were sufficient to cause an increase in plant height when compared to treatments without B application at planting, at 21 months. At 24 months after planting, an increase in leaf B was observed in treatments with foliar application. However, this did not improve growth, diameter at breast height (DBH) or timber volume of the eucalyptus clone. Both the application of $\mathrm{B}$ at planting (independent of the source used) and the foliar application of the element were sufficient to reduce the symptoms of $\mathrm{B}$ deficiency. With respect to the sources used at planting, at a dose of $1 \mathrm{~kg} \mathrm{ha}^{-1}$ of B, both sources produced similar results for plant height, DBH and timber volume.
\end{abstract}

Key words: Eucalyptus spp., micronutrient, solubility

\section{Resumo}

Os solos de Cerrado apresentam baixo teor de boro (B) no solo, sendo comum a suplementação deste elemento através da adubação via solo e/ou foliar. Portanto, é importante definir qual o melhor modo de aplicação e fonte de B para o bom desenvolvimento do eucalipto. Assim, o objetivo deste trabalho foi comparar o efeito de fontes de B com alta e baixa solubilidade na cultura do eucalipto, bem como a aplicação foliar do micronutriente. O experimento foi conduzido em uma área com latitude $20^{\circ} 34^{\prime} \mathrm{S}$ e longitude $51^{\circ} 50^{\prime} \mathrm{O}$ e altitude de $305 \mathrm{~m}$, no período de $01 / 2012$ a $02 / 2014$. O delineamento experimental foi o de blocos casualizados com seis tratamentos e cinco repetições, dispostos em um esquema fatorial

1 Discentes do Curso de Doutorado em Agronomia, Universidade Estadual Paulista "Júlio de Mesquita Filho", FE, UNESP, Ilha Solteira, SP, Brasil. E-mail: thiagocelestrino@yahoo.com.br; rngazola@gmail.com; raissa_dinalli@terra.com.br

2 Profs. Titulares, FE/UNESP, Ilha Solteira, SP, Brasil. E-mail: sbuzetti@agr.feis.unesp.br; mcmteixeirafilho@agr.feis.unesp.br

3 Assistente Técnico-Científico, Instituto de Pesquisas e Estudos Florestais, IPEF, Piracicaba, SP, Brasil. E-mail: paulohenrique@ ipef.br

4 Discentes do Curso de Graduação em Agronomia, FE/UNESP, Ilha Solteira, SP, Brasil. E-mail: ariadne2carvalho@gmail.com; guilhermedsarto@gmail.com

* Author for correpondence 
de $3 \times 2$, sendo: $0 \mathrm{~kg} \mathrm{ha}^{-1}$ de B, $1 \mathrm{~kg} \mathrm{ha}^{-1}$ de B utilizando como fonte o ácido bórico (alta solubilidade, $17 \%$ B) oul $\mathrm{kg} \mathrm{ha}^{-1}$ de B utilizando como fonte o borogran (baixa solubilidade, 10\% B), aplicados no sulco de plantio, com ou sem aplicações de ácido bórico via foliar na dose de $0,5 \%$ de ácido bórico na calda com volume de $250 \mathrm{~L} \mathrm{ha}^{-1}$. Com a omissão de B via foliar houve incremento em altura de plantas nos tratamentos que receberam a aplicação do micronutriente no plantio, diferindo significativamente da testemunha. Porém, ambas as fontes, independente da solubilidade, apresentaram resultados semelhantes. As duas aplicações de B via foliar foram suficientes para que houvesse incremento em altura de plantas, quando comparadas aos tratamentos que não receberam aplicação de B no plantio, aos 21 meses. Aos 24 meses após o plantio foi constatado aumento no teor foliar de B nos tratamentos que receberam aplicação foliar. No entanto, esta não incrementou o crescimento, DAP e volume de madeira do clone de eucalipto. A aplicação de B no plantio, independente da fonte utilizada, assim como aplicação foliar do elemento, foram suficientes para reduzir os sintomas de deficiência de B. Com relação às fontes utilizadas no plantio, na dose de $1 \mathrm{~kg} \mathrm{ha}^{-1} \mathrm{de} \mathrm{B}$, ambas apresentaram resultados semelhantes para altura de planta, DAP e volume de madeira.

Palavras-chave: Eucalyptus spp., micronutriente, solubilidade

\section{Introduction}

The forestry sector plays a key role in Brazilian agribusiness, contributing to the production of goods and services and directly and indirectly generating jobs, which reached 4.4 million people employed by the sector in 2012. The area of planted forests in Brazil was $6,664,812$ hectares in $2012,76.6 \%$ of which corresponds to areas planted with the genus Eucalyptus spp. (ABRAF, 2013). This is due to numerous factors that favour large-scale planting of this species, such as rapid growth in a short rotation cycle, high forest productivity and expansion and targeting of new investments by companies that utilise wood as a raw material in industrial processes (ABRAF, 2010).

Eucalyptus production in Brazil is among the most productive in the world; however, eucalyptus cultivation in Cerrado areas is increasingly frequent, with great limitations on plant growth due to the soil's high nutritional deficiency, aluminium content and low water availability (PAVAN, 2003). Because of this natural condition, the use of additives and fertilizers is considered a mandatory practice to avoid compromising productivity and sustainability over the years (NOVAIS et al., 1990; MARTINS et al., 2004; ROCHA et al., 2004). With the intensified clonal propagation of eucalyptus and the planting of more productive genetic materials that are potentially more nutrient-demanding, symptoms of micronutrient deficiency, especially of boron (B), copper $(\mathrm{Cu})$ and zinc $(\mathrm{Zn})$, have been observed, particularly in Cerrado areas (PINHEIRO, 1999; BOUCHARDET, 2002).

Organic matter is considered the primary source of B in tropical soils because B assimilated by a plant is almost entirely derived from organic matter mineralization (MALAVOLTA, 1980; GUPTA et al., 1985; GUPTA, 1993). This is evident in the findings of Vanderlei et al. (1988) and Malavolta (1980), who observe a positive relationship between the amount of soil organic matter (SOM) and available $\mathrm{B}$ content, in which the highest $\mathrm{B}$ concentrations are found in the soil surface layers. However, tropical soils generally have low SOM levels due to high temperatures that favour mesophilic and thermophilic micro-organisms, accelerating the rate of SOM decomposition and hindering the maintenance of high levels of SOM (Sanchez, 1981). Because SOM is the most important primary source of B, its use is limited to crops with high nutritional demands. Another factor that influences the availability of B to a crop is the fact that mass flow is the dominant $\mathrm{B}$ transport mechanism and can meet $100 \%$ of the plant demand at the highest nutrient doses (MATTIELLO et al., 2009). Because the Cerrado region experiences a few months of drought, mass flow is reduced and the plants 
are subject to B deficiency. With respect to the adsorption of this element, according to Steiner et al. (2012), the $\mathrm{pH}$ and exchangeable Al, clay and iron oxide contents are the soil properties that most affect that adsorption.

Although the function of $\mathrm{B}$ in the plant metabolism is still not entirely clear, there is evidence that this element plays roles in cell elongation, nucleic acid synthesis, hormonal responses, membrane functioning and cell cycle regulation (BROWN et al., 2002; REGUERA et al., 2009). In this context, the importance of $B$ in forest plantations is associated with wood quality because it acts in meristematic growth and cell wall formation and, more specifically, in the synthesis of pectin, lignin and cellulose (MARSCHNER, 1995).

The application of micronutrients to the soil aims to increase the concentration of elements in the soil solution, which is absorbed by the roots. Thus, to prevent possible losses, it is necessary for the micronutrient sources used to solubilise in the soil at a speed that is at least compatible with root uptake (LOPES, 1991; VOLKWEISS, 1991). Similar to roots, leaves can absorb nutrients deposited on their surface in the form of a solution. Thus, the practice of foliar fertilization has emerged as an alternative in which solutions of one or more nutrients are sprayed on the shoots, primarily reaching the leaves (VOLKWEISS, 1991). Due to the immobility of B in the phloem of some species, its foliar application is questionable (FAQUIN, 2005). Data on forest foliar fertilization are scarce, and in the case of eucalyptus, more studies are necessary to determine its efficiency (DAHMARDEH et al., 2011).

The B retention capacity of sandy soils is lower, interfering in the maintenance of an adequate element supply in the soil solution. Therefore, some technical recommendations indicate that in these soils, a greater parcelling of doses is necessary when using more soluble sources. Another option is the use of sources with low solubility, such as the calcium borates: ulexite and colemanite, which release B more gradually, reducing the risk of toxicity (SILVEIRA et al., 2002). For borate fertilization in eucalyptus plantations, Silveira et al. (2001) report that low-solubility B sources are more efficient because the element is continuously supplied over time. For areas with good rainfall, the authors recommend two topdressing applications, at 2 and 9 months after planting. For sandy soils in areas affected by drought, the parcelling of borate fertilization primarily occurs at the end of the rainy season, reducing losses of the element by leaching and providing a more continuous supply of B in the period of increasing occurrence of dieback, which occurs during the first two years of cultivation. According to Paula (2009), the combined application of B to the soil and leaf was able to prevent desiccation of the branch tips, which is a characteristic symptom of B deficiency, especially during drought.

Because Cerrado soils have low levels of B, combined with the fact that they have a sandy texture, $\mathrm{B}$ fertilization in the planting furrow and via the leaves is common during the crop-implantation phase. Therefore, it is important to establish the best mode of application and source of B for the proper development and productivity of eucalyptus, with possible cost savings. Thus, the objective of this study was to compare the effect of B sources, with high and low solubility, on eucalyptus cultivation either with or without foliar B application.

\section{Materials and Methods}

The experiment was implemented in January 2012 at a farm located in the county of Três Lagoas, Mato Grosso do Sul, Brazil, at 20 34' S latitude, $51^{\circ}$ $50^{\prime} \mathrm{W}$ longitude at an altitude of approximately 305 $\mathrm{m}$. According to Köppen, the climate classification is Aw, defined as tropical humid with a rainy season in the summer and a dry season in the winter. The rainfall $(\mathrm{mm})$ recorded during the experimental period is shown in Figure 1. 
Figure 1. Monthly precipitation $(\mathrm{mm})$ recorded at the Automated Meteorological Station of Três Lagoas, Mato Grosso do Sul, Brazil, during the experiment.

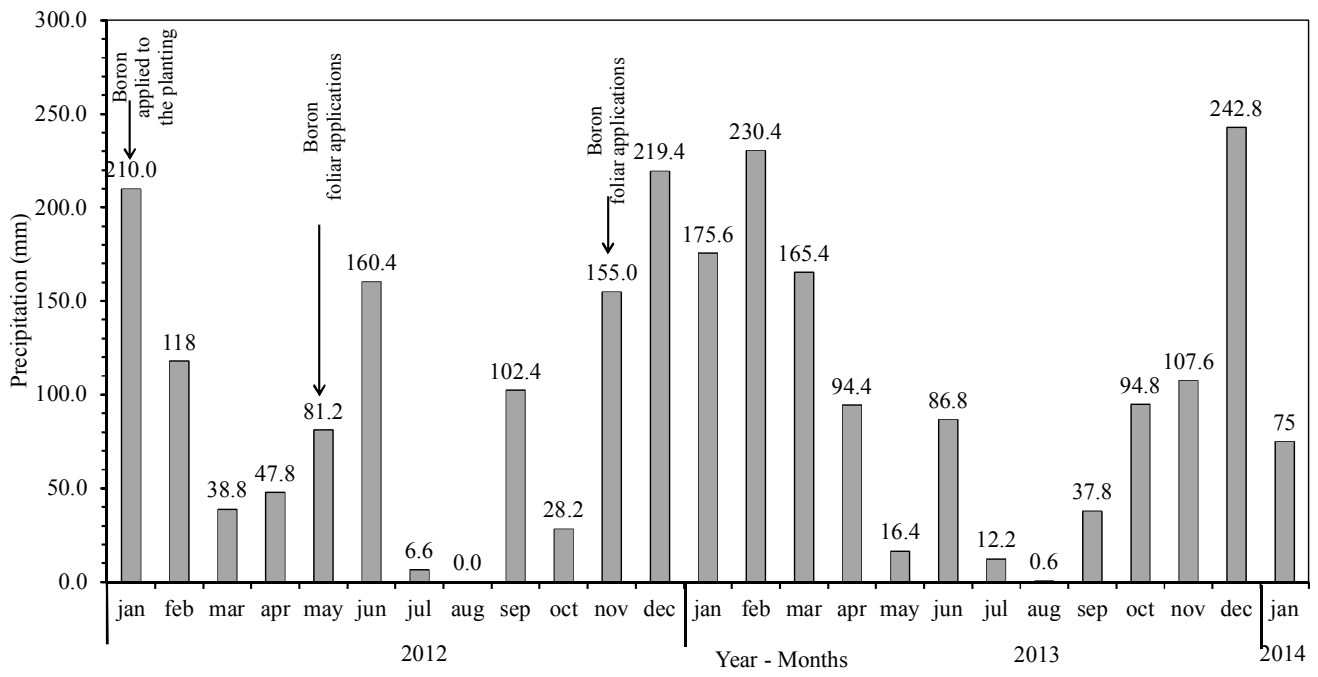

The soil is classified as Orthic Quartzarenic Neosol according to the Brazilian system of soil classification (EMBRAPA, 2013), with particle size values of 85,17 and $898 \mathrm{~g} \mathrm{~kg}^{-1}$ of clay, silt and sand, respectively, in the $0.00-0.20 \mathrm{~m}$ layer.
The chemical characteristics of the soil were determined before beginning the experiment, according to the method proposed by Raij et al. (2001), in which samples were taken from the 0.00-0.20 and 0.20-0.40 m layers. According to Technical Bulletin 100 (Raij et al., 1997), prior to the installation of the experiment, the soil had medium B content (Table 1).

Table 1. Initial chemical characterisation of the experimental area. Três Lagoas, Mato Grosso do Sul, Brazil, 2011.

\begin{tabular}{|c|c|c|c|c|c|c|c|c|c|}
\hline Prof. & $\mathrm{P}_{\text {resina }}$ & MO & $\mathrm{pH}$ & $\mathrm{K}$ & $\mathrm{Ca}$ & $\mathrm{Mg}$ & $\mathrm{H}+\mathrm{Al}$ & $\mathrm{Al}$ & SB \\
\hline$(\mathrm{cm})$ & $\mathrm{mg} \mathrm{dm}^{-3}$ & $\mathrm{~g} \mathrm{dm}^{-3}$ & $\mathrm{CaCl}_{2}$ & \multicolumn{6}{|c|}{$\mathrm{mmol}_{\mathrm{c}} \mathrm{dm}^{-3}$} \\
\hline $0-20$ & 1 & 7.4 & 4.2 & 0.2 & 4.2 & 1.9 & 17 & 4.3 & 6.3 \\
\hline $20-40$ & 1 & 6.8 & 4.2 & 0.3 & 1.6 & 1.1 & 18 & 4.5 & 3.0 \\
\hline Prof. & CTC & $\mathrm{V}$ & $\mathrm{m}$ & $\mathrm{S}-\mathrm{SO}_{4}^{2-}$ & $\mathrm{B}$ & $\mathrm{Cu}$ & $\mathrm{Zn}$ & $\mathrm{Mn}$ & $\mathrm{Fe}$ \\
\hline$(\mathrm{cm})$ & $\mathrm{mmol} \mathrm{dm}^{-3}$ & $\%$ & & \multicolumn{6}{|c|}{$\mathrm{mg} \mathrm{dm}^{-3}$} \\
\hline $0-20$ & 23.3 & 27 & 25 & 4.7 & 0.27 & 0.4 & 0.2 & 1.5 & 13 \\
\hline $20-40$ & 21.0 & 14 & 25 & 4.0 & 0.20 & 0.5 & 0.2 & 1.4 & 20 \\
\hline
\end{tabular}

The extraction method used for the cationic micronutrients was DTPA, for boron was hot water.

Based on a chemical analysis of the soil and the history of the area, which had been a degraded pasture cultivated with Urochloa brizantha (Syn. Brachiaria) for 20 years with high weed infestation, it was necessary to apply lime at a dose of $1,500 \mathrm{~kg}$ $\mathrm{ha}^{-1}$ with relative power of the total neutralization of $80 \%$, applied by broadcasting on the soil surface.
To improve subsurface conditions, gypsum was applied at a dose of $500 \mathrm{~kg} \mathrm{ha}^{-1}$ by broadcasting on the soil surface. These applications occurred in September 2011. In November 2011, $3 \mathrm{~kg} \mathrm{ha}^{-1}$ of granular ant bait $\left(0.9 \mathrm{~g} \mathrm{ha}^{-1}\right.$ of the active ingredient (a.i.) sulfluramid) was applied to combat ants. In December, the native trees were cut and removed, 
followed by complete mechanical mowing, road opening, fence construction and combating against ants prior to planting. In January 2012, $6 \mathrm{~L} \mathrm{ha}^{-1}$ of herbicide (2880 $\mathrm{g} \mathrm{ha}^{-1}$ of the a.i. glyphosate) was applied to eradicate weeds. The soil was prepared, which consisted of subsoiling, plowing, harrowing and furrowing only in the planting rows. Planting was performed on January 27, 2012, using clone I144 seedlings (a spontaneous hybrid of Eucalyptus urophylla), followed by watering for better fixation of the seedlings. Two weeks after planting, $150 \mathrm{~g}$ $\mathrm{ha}^{-1}$ of a pre-emergent herbicide (112.5 $\mathrm{g} \mathrm{ha}^{-1}$ of the a.i. isoxaflutole) was applied for weed control.

Fertilization at planting was performed manually in January 2012 in a continuous stream by applying NPK to the planting furrow using $150 \mathrm{~kg} \mathrm{ha}^{-1}$ of a 10-27-10 formula combined with $30 \mathrm{~kg} \mathrm{ha}^{-1}$ of $\mathrm{P}_{2} \mathrm{O}_{5}$ in the form of triple superphosphate $\left(45 \% \mathrm{P}_{2} \mathrm{O}_{5}\right)$. At planting, fertilization with $\mathrm{Cu}$ and $\mathrm{Zn}$ at a dose of $1 \mathrm{~kg} \mathrm{ha}^{-1}$ was performed using copper sulphate and zinc sulphate fertilizers, respectively. Broadcast fertilizations of nitrogen and potassium were performed manually in a semicircle at 2; 9 and 14 months after planting. At the time of each nitrogen broadcast fertilization, ammonium nitrate was used in the dose of $40 \mathrm{~kg} \mathrm{ha}^{-1}$ of $\mathrm{N}$, and for $\mathrm{K}$, potassium chloride was used at a dose of $50 \mathrm{~kg} \mathrm{ha}^{-1}$ of $\mathrm{K}_{2} \mathrm{O}$.

The experiment followed a randomised complete block design with six treatments and five replications in a $3 \times 2$ factorial scheme, which consisted of two sources of B applied at planting and one control, with and without foliar application. Each block measured $3.0 \times 2.5 \mathrm{~m}$, and the total area was 12,600 $\mathrm{m}^{2}$. Each plot consisted of 56 plants, distributed into seven rows of eight plants each, for a total area of $420 \mathrm{~m}^{2}$. The working area of the plot was $225 \mathrm{~m}^{2}$ because the two outside rows were excluded, along with the first and last plant of each working row, thus totalling 30 plants.

In treatment 1 (T1) there was no external source of $\mathrm{B}$, and thus, the crop responded only to the concentration of B available in the soil. Treatment 2 (T2) consisted of the application of borogran fertilizer (low solubility, 10\% B) at a dose of $1 \mathrm{~kg}$ $\mathrm{ha}^{-1}$ of $\mathrm{B}$, manually applied in a continuous stream to the planting furrow. In treatment 3 (T3), a boric acid fertilizer was applied (high solubility, 17\% B) at a dose of $1 \mathrm{~kg} \mathrm{ha}^{-1}$ of B, manually applied in a continuous stream to the planting furrow. The dose of $1 \mathrm{~kg} \mathrm{ha}^{-1}$ of $\mathrm{B}$ in the furrow followed the recommendation of Technical Bulletin 100 (RAIJ et al., 1997). Treatments 4 (T4) and 5 (T5) were similar to $\mathrm{T} 2$ and $\mathrm{T} 3$, respectively, however, in addition to the application of borate fertilizers to the planting furrow, both treatments (T4 and T5) received foliar applications of $\mathrm{B}$ at four and ten months after planting. At each foliar application, $0.5 \%$ boric acid in a solution with a volume of $250 \mathrm{~L} \mathrm{ha}^{-1}$ was used; these applications were performed in the morning with the aid of a backpack pump. Mineral oil ( $0.2 \%)$ was added to the solution to increase contact with the leaf, to reduce drift and to slow evaporation of the droplet. In treatment 6 (T6), there was no application $\mathrm{B}$ to the planting furrow but only foliar application of B, as in T4 and T5.

The characteristics evaluated were as follows: plant height $(\mathrm{H})$ using the Forestor Vertex device, which consisted of a hypsometer and a transmitter (transponder) (CAMPOS; LEITE, 2002); DBH with the aid of a tape measure, measuring the circumference and subsequently using the equation $\mathrm{DBH}=\mathrm{C} / \mathrm{p}$, where $\mathrm{C}=$ circumference at $1.30 \mathrm{~m}$ high $(\mathrm{cm})$; and total timber volume with bark $\left(\mathrm{m}^{3}\right.$ $\mathrm{h}^{-1}$ ), calculated using the equations

$$
\begin{aligned}
& \mathrm{Vtb}=\Sigma(\mathrm{Vi} / \mathrm{Ai}) * 10000, \\
& \mathrm{Vi}=\pi^{*}(\mathrm{DBHi}) 2 * \mathrm{ff} * \mathrm{Hi},
\end{aligned}
$$

In those equations, $\mathrm{V}_{\mathrm{tc}}=$ total volume with bark $\left(\mathrm{m}^{3} \mathrm{ha}^{-1}\right), \mathrm{V}_{\mathrm{i}}=$ timber volume with bark of the tree, $\mathrm{A}_{\mathrm{i}}=$ working area of the plot $\left(225 \mathrm{~m}^{2}\right), \mathrm{DBH}_{\mathrm{i}}=$ diameter at breast height of each tree $(\mathrm{m})$; $\mathrm{ff}=$ form factor (in this case, due to the lack of regionally defined factors for the clone under study, a value of 0.5 was attributed) and $H_{i}=$ total height of each tree $(\mathrm{m})$. All of the above-cited characteristics were evaluated with plants at the age of 12,15, 18, 21 and 24 months. 
To obtain the foliar concentration of macro and micronutrients, 10 trees per plot were sampled at 24 months of age, according to the method described by Malavolta et al. (1997), in which representative samples of the penultimate mature leaves on branches located in the upper third of the canopy in the four cardinal directions are collected. The samples were sent for chemical analysis at the Laboratory of Plant Nutrition of the São Paulo State University (Universidade Estadual Paulista, UNESP, Ilha Solteira campus), where they were dried in a forced air oven $\left(65^{\circ} \mathrm{C}\right)$ for 72 hours and then ground in a Wiley mill. Samples were digested (sulphuric for $\mathrm{N}$; nitropercloric for $\mathrm{P}, \mathrm{K}, \mathrm{Ca}, \mathrm{Mg}$, $\mathrm{S}, \mathrm{Cu}, \mathrm{Fe}, \mathrm{Mn}$ and $\mathrm{Zn}$, and incineration for $\mathrm{B}$ ) to determine the leaf macro and micronutrients as described by Malavolta et al. (1997).

The quality of the trunk was evaluated in all of the trees in the plot until 24 months of age by visually observing the percentage of bifurcated plants because this is a characteristic symptom of B deficiency due to the loss of apical dominance.

All results were subjected to analysis of variance, and the means were analysed using the Tukey test at $5 \%$ probability in the program SISVAR (FERREIRA, 2008).

\section{Results and Discussion}

The B sources applied at planting, along with the foliar application $\mathrm{B}$, did not influence plant height up to 24 months after planting (Table 2). However, there was a significant interaction effect at 21 months after planting between the sources of $\mathrm{B}$ applied at planting and the presence or absence of foliar micronutrient application on increase in tree height, the breakdown of which is shown in Table 3 . In the absence of foliar application, B sources applied to the planting furrow differed from the control, resulting in greater growth in plant height; however, there was no difference between sources. The absence of B results in plant growth inhibition because this element comprises part of the cell-wall structure (EPSTEIN; BLOOM, 2006). Novelino et al. (1982), Silveira et al. (2000) and Maffeis et al. (2000) also report that the absence of B application significantly reduced growth in height in Eucalyptus citriodora. Oliveira et al. (2001), when studying the effect of NPK fertilization in the presence and absence of B in Eucalyptus citriodora, find that in soil with medium B content, two broadcast applications of B at 24 and 28 months of age at a dose of $1 \mathrm{~kg} \mathrm{ha}^{-1}$ of B each resulted in greater plant height only at 7 years of age.

Table 2. Mean eucalyptus height according to boron treatment. Três Lagoas, Mato Grosso do Sul, Brazil, $2013 / 2014$.

\begin{tabular}{|c|c|c|c|c|c|}
\hline \multirow{2}{*}{ Treatments } & \multicolumn{4}{|c|}{ Height $(\mathrm{m})$ in the evaluated ages } & \multirow[b]{2}{*}{24 months } \\
\hline & 12 months & 15 months & 18 months & 21 months & \\
\hline \multicolumn{6}{|l|}{ Planting (P) } \\
\hline Control & $6.36 \mathrm{a}$ & $10.18 \mathrm{a}$ & $11.69 \mathrm{a}$ & 11.77 & $13.19 \mathrm{a}$ \\
\hline Boric acid & $6.72 \mathrm{a}$ & $10.44 \mathrm{a}$ & $11.90 \mathrm{a}$ & 12.12 & $13.19 \mathrm{a}$ \\
\hline Borogran & $6.69 \mathrm{a}$ & $10.69 \mathrm{a}$ & $11.91 \mathrm{a}$ & 11.92 & $13.26 \mathrm{a}$ \\
\hline DMS & 0.36 & 0.63 & 0.55 & 0.60 & 0.48 \\
\hline \multicolumn{6}{|l|}{ Foliar $(\mathrm{F})$} \\
\hline With & $6.66 \mathrm{a}$ & $10.59 \mathrm{a}$ & $11.97 \mathrm{a}$ & 12.04 & $13.25 \mathrm{a}$ \\
\hline Without & $6.51 \mathrm{a}$ & $10.28 \mathrm{a}$ & $11.69 \mathrm{a}$ & 11.83 & $13.18 \mathrm{a}$ \\
\hline DMS & 0.24 & 0.43 & 0.37 & 0.40 & 0.32 \\
\hline \multicolumn{6}{|l|}{ Test $\mathrm{F}$} \\
\hline $\mathrm{P}$ & $3.31^{\mathrm{ns}}$ & $2.07^{\mathrm{ns}}$ & $0.65^{\text {ns }}$ & $1.12^{\mathrm{ns}}$ & $0.09^{\text {ns }}$ \\
\hline $\mathrm{F}$ & $1.73^{\mathrm{ns}}$ & $2.34^{\mathrm{ns}}$ & $2.48^{\mathrm{ns}}$ & $1.16^{\mathrm{ns}}$ & $0.19^{\mathrm{ns}}$ \\
\hline $\mathrm{P} \times \mathrm{F}$ & $2.08^{\mathrm{ns}}$ & $1.93^{\mathrm{ns}}$ & $0.34^{\mathrm{ns}}$ & $7.06^{*}$ & $1.70^{\mathrm{ns}}$ \\
\hline C.V. $(\%)$ & 4.85 & 5.37 & 4.11 & 4.40 & 3.19 \\
\hline General mean & 6.59 & 10.43 & 11.83 & 11.94 & 13.21 \\
\hline
\end{tabular}

$\mathrm{ns} ;{ }^{*}$ - not significant and significant by the $\mathrm{F}$ test, at $5 \%$ probability.

Means followed by the same letter in the column do not differ by Tukey test at $5 \%$ probability. 
Table 3. Breakdown of the interaction between boron application at planting and foliar application on the height of plants at 21 months after planting. Três Lagoas, Mato Grosso do Sul, Brazil, 2013.

\begin{tabular}{cccc}
\hline \multirow{2}{*}{ Planting } & \multicolumn{3}{c}{ Foliar } \\
\cline { 2 - 4 } & With & Without \\
\hline Control & $12.38 \mathrm{a} \mathrm{A}$ & $11.16 \mathrm{~b} \mathrm{~B}$ \\
Boric acid & $11.92 \mathrm{a}$ & $12.32 \mathrm{a}$ \\
Borogran & $11.82 \mathrm{a}$ & & $12.02 \mathrm{a}$ \\
\hline DMS $_{(\mathrm{P})}$ & 0.84 & \\
DMS $_{(\mathrm{P})}$ & & 0.69 & \\
\hline
\end{tabular}

Means followed by different lowercase letters in columns and capitals letter in lines differ by Tukey test to a level of $5 \%$ probability.

Paula (2009) studied B sources with different solubilities in Red Yellow Latosol and found that the dose of $4 \mathrm{~kg} \mathrm{ha}^{-1}$ of $\mathrm{B}$ applied in a continuous stream over the canopy projection in soil with B concentration of $0.21 \mathrm{mg} \mathrm{dm}^{-3}$ does not affect Eucalyptus urophylla height until 20 months of age. However, Bouchardet (2002), when evaluating $\mathrm{B}$ doses in Eucalyptus grandis clones, found that the dose of $0.5 \mathrm{~kg} \mathrm{ha}^{-1}$ of $\mathrm{B}$ results in plant height increases of up to $48 \%$ compared to the control at 12 months of age and of $27 \%$ at 24 months of age. As in that study, here it was found that applications of B at planting increased plant height compared to the control; however, both sources yielded similar results.

The responses to B application in eucalyptus are quite different. Tirloni et al. (2011) found that B applications both at the beginning of the dry season and in the rainy season did not influence plant height of Corymbia citriodora up to 29 months of age. Barros and Novais (1996) did not observe a significant effect of B application on plant height of Eucalyptus citriodora, even noting a decreasing trend in plant height with application of the element. Coutinho et al. (1995) also observed a height decrease in Eucalyptus globulus when applying doses of 4.4 to $8.8 \mathrm{~kg} \mathrm{ha}^{-1}$ of $\mathrm{B}$, which is most likely related to the phytotoxicity of that micronutrient. Pinheiro (1999) found that increasing doses of B applied as topdressing at 15 months of age, using borax fertilizer as a source of $B$, resulted in increasing plant height, with an ideal dose of $1.1 \mathrm{~g} \mathrm{plant}^{-1}(1.8$ $\mathrm{kg} \mathrm{ha}^{-1}$ of B) for maximum growth of Eucalyptus camaldulensis. Regarding to foliar application of B to eucalyptus plants, at 21 months, it was observed in this study that when there was omission of B at planting, there was a significant response in plant height for the treatments with foliar application when compared with treatments not receiving foliar application. However, at 24 months, this effect was attenuated because regardless of the source or mode of application, there was no difference in plant height. One possible explanation is that this soil, by having medium B concentration, was sufficient to nourish the plants even in the absence of B application when compared to the treatments subjected to the sources and application modes.

Up to 24 months after planting, there was no difference in DBH among the B sources applied at planting or an effect of the foliar application of the element (Table 4), indicating that the medium concentration of B in the soil was sufficient for plant development up to 24 months of age. Paula (2009), when studying B sources with different solubilities at a dose of $4 \mathrm{~kg} \mathrm{ha}^{-1}$ of $\mathrm{B}$ applied in a continuous stream over the canopy projection in soil with medium B concentration, found no increase in $\mathrm{DBH}$ for Eucalyptus urophylla hybrids until 20 months of age. The same author found that doses of $4 \mathrm{~kg} \mathrm{ha}^{-1}$ of B using a source with medium solubility promoted significant increases in $\mathrm{DBH}$ when compared to the control. Barretto et al. (2007), working in a greenhouse, obtained a linear increase in diameter in Eucalyptus grandis x E. urophylla hybrids with 
doses of $0,0.135,0.27$ and $0.54 \mathrm{mg} \mathrm{L}^{-1}$ of $\mathrm{B}$, using boric acid (17\% B).

In a long-term experiment, Oliveira et al. (2001), studying the effect of nitrogen, phosphorous and potassium (NPK) fertilization with the presence and absence of B in Eucalyptus citriodora, found that in soil with medium B concentration, there was an increase in DBH from 5 to 8 years of age; however, this effect was attenuated at 13 years of age. Tirloni et al. (2011) reported that applications of B, both at the beginning of the dry season and in the rainy season, did not significantly influence the DBH of Corymbia citriodora up to 29 months of age. In this study, no increase in DBH of trees up to 24 months after planting was observed.

Table 4. Mean diameter at breast height (DBH) of eucalyptus following boron treatments. Três Lagoas, Mato Grosso do Sul, Brazil, 2013/2014.

\begin{tabular}{|c|c|c|c|c|c|}
\hline \multirow{2}{*}{ Treatments } & \multicolumn{4}{|c|}{ DBH $(\mathrm{cm})$ in the evaluated ages } & \multirow[b]{2}{*}{24 months } \\
\hline & 12 months & 15 months & 18 months & 21 months & \\
\hline \multicolumn{6}{|l|}{ Planting $(\mathrm{P})$} \\
\hline Control & $5.68 \mathrm{a}$ & $8.50 \mathrm{a}$ & $8.87 \mathrm{a}$ & $9.21 \mathrm{a}$ & $10.37 \mathrm{a}$ \\
\hline Boric acid & $5.88 \mathrm{a}$ & $8.39 \mathrm{a}$ & $8.82 \mathrm{a}$ & $9.17 \mathrm{a}$ & $10.22 \mathrm{a}$ \\
\hline Borogran & $5.88 \mathrm{a}$ & $8.61 \mathrm{a}$ & $8.76 \mathrm{a}$ & $9.12 \mathrm{a}$ & $10.38 \mathrm{a}$ \\
\hline DMS & $0,0.31$ & 0.32 & 0.34 & 0.62 & 0.44 \\
\hline \multicolumn{6}{|l|}{ Foliar (F) } \\
\hline With & $5.83 \mathrm{a}$ & $8.55 \mathrm{a}$ & $8.75 \mathrm{a}$ & $9.17 \mathrm{a}$ & $10.35 \mathrm{a}$ \\
\hline Without & $5.79 \mathrm{a}$ & $8.45 \mathrm{a}$ & $8.89 \mathrm{a}$ & $9.16 \mathrm{a}$ & $10.29 \mathrm{a}$ \\
\hline DMS & 0.21 & 0.21 & 0.23 & 0.42 & 0.29 \\
\hline \multicolumn{6}{|l|}{ Test F } \\
\hline $\mathrm{P}$ & $1.72^{\mathrm{ns}}$ & $1.56^{\mathrm{ns}}$ & $0.33^{\mathrm{ns}}$ & $0.07^{\mathrm{ns}}$ & $0.54^{\mathrm{ns}}$ \\
\hline $\mathrm{F}$ & $0.15^{\mathrm{ns}}$ & $1.10^{\mathrm{ns}}$ & $1.62^{\mathrm{ns}}$ & $0.01^{\mathrm{ns}}$ & $0.18^{\mathrm{ns}}$ \\
\hline $\mathrm{P} \times \mathrm{F}$ & $2.54^{\mathrm{ns}}$ & $0.99^{\text {ns }}$ & $1.20^{\mathrm{ns}}$ & $3.47^{\mathrm{ns}}$ & $0.38^{\mathrm{ns}}$ \\
\hline C.V. $(\%)$ & 4.78 & 3.28 & 3.42 & 5.95 & 3.75 \\
\hline General mean & 5.81 & 8.50 & 8.82 & 9.17 & 10.32 \\
\hline
\end{tabular}

ns - not significant by the $\mathrm{F}$ test, at $5 \%$ probability.

Means followed by the same letter in the column do not differ by Tukey test at $5 \%$ probability.

Regarding the volume of timber with bark $\left(\mathrm{m}^{3}\right.$ $\left.\mathrm{ha}^{-1}\right)$, there was no difference between the control and the B sources applied at planting, or between the application or not of B to the leaves (Table 5). Barros (1982) found that applications from 1.0 to $1.5 \mathrm{~g}$ of B plant $\mathrm{t}^{-1}$ resulted in gains in timber volume on the order of $32 \%$ in relation to the application of NPK without B. Fonseca et al. (1990) also reported gains in volume on the order of $25 \%$ compared to the control, in treatments subjected to a dose of 1.0 $\mathrm{g}$ of B plant ${ }^{-1}$ in Eucalyptus camaldulensis, using low solubility fertilizer. In this work, using the dose of $0.75 \mathrm{~g}$ of B plant ${ }^{-1}$ at planting, similar results were only observed after 24 months after planting because no increase in timber volume was observed in treatments that received either B application or foliar application of the micronutrient As in the other measurements. One possible explanation is that the medium content of B in the soil was sufficient for crop development. 
Table 5. Values of timber volume with bark for eucalyptus following boron treatment. Três Lagoas, Mato Grosso do Sul, Brazil, 2013/2014.

\begin{tabular}{cccccc}
\hline \multirow{2}{*}{ Treatments } & \multicolumn{5}{c}{ Volume $\left(\mathrm{m}^{3} \mathrm{ha}^{-1}\right)$ in the evaluated ages } \\
\cline { 2 - 5 } & 12 months & 15 months & 18 months & 21 months & 24 months \\
\hline Planting (P) & & & & \\
Control & $10.8 \mathrm{a}$ & $38.66 \mathrm{a}$ & $48.20 \mathrm{a}$ & $52.66 \mathrm{a}$ & $74.57 \mathrm{a}$ \\
Boric acid & $12.2 \mathrm{a}$ & $38.48 \mathrm{a}$ & $48.55 \mathrm{a}$ & $53.95 \mathrm{a}$ & $72.35 \mathrm{a}$ \\
Borogran & $12.2 \mathrm{a}$ & $41.64 \mathrm{a}$ & $48.06 \mathrm{a}$ & $52.38 \mathrm{a}$ & $74.91 \mathrm{a}$ \\
\hline DMS & 1.50 & 4.39 & 5.48 & 9.25 & 8.27 \\
\hline Foliar (F) & & & & \\
With & $11.9 \mathrm{a}$ & $39.71 \mathrm{a}$ & $48.09 \mathrm{a}$ & $53.67 \mathrm{a}$ & $74.54 \mathrm{a}$ \\
Without & $11.5 \mathrm{a}$ & $39.47 \mathrm{a}$ & $48.44 \mathrm{a}$ & $52.32 \mathrm{a}$ & $73.35 \mathrm{a}$ \\
\hline DMS & 1.00 & 2.96 & 3.69 & 6.23 & 5.56 \\
\hline Test F & & & & \\
P & $3.31^{\text {ns }}$ & $2.09^{\text {ns }}$ & $0.03^{\text {ns }}$ & $0.10^{\text {ns }}$ & $0.36^{\text {ns }}$ \\
F & $0.72^{\text {ns }}$ & $0.03^{\text {ns }}$ & $0.04^{\text {ns }}$ & $0.21^{\text {ns }}$ & $0.20^{\text {ns }}$ \\
P x F & $2.84^{\text {ns }}$ & $1.81^{\text {ns }}$ & $0.30^{\text {ns }}$ & $4.33^{\text {ns }}$ & $0.76^{\text {ns }}$ \\
\hline C.V. $(\%)$ & 11.48 & 9.80 & 10.03 & 15.42 & 9.88 \\
\hline General mean & 11.70 & 39.59 & 48.27 & 53.00 & 73.94 \\
\hline
\end{tabular}

ns - not significant by the $\mathrm{F}$ test, at $5 \%$ probability.

Means followed by the same letter in the column do not differ by Tukey test at $5 \%$ probability.

Paula (2009), studying B sources with different solubilities and application methods, observed no increase in timber volume in Eucalyptus urophylla hybrids until 20 months of age. Oliveira et al. (2001) found that the application of B in Eucalyptus citriodora in soil with medium B concentration resulted in timber volume increase from 5 to 8 years of age. However, in this study, performed in a sandy soil with medium B content, no significant difference in increase in timber volume up to 24 months of age was observed as a function of the $\mathrm{B}$ source or mode of application.

The dose of $1 \mathrm{~kg} \mathrm{ha}^{-1}$ of $\mathrm{B}$, according to some authors, is considered low for sandy soils with low organic matter content, although in this study, even plants in the control treatment had B leaf concentrations above the range considered adequate according to Dell et al. (2001) of 15 to $27 \mathrm{mg} \mathrm{kg}^{-}$ 1. Another possible explanation for the lack of difference in timber volume until 24 months after planting may be a function of clone I144 requiring higher doses than applied to express their genetic potential. This clone is more demanding than traditional varieties, as demonstrated by a greater bifurcation index in the treatments with no $\mathrm{B}$ application, whether to the soil or to the leaves (Table 6). Pinheiro (1999), in an area with predominance of Red Yellow Latosol, noted that increasing B doses applied as topdressing at 15 months of age in Eucalyptus camaldulensis, using borax fertilizer as source of B, resulted in a linear increase in timber volume up to a dose of $4.4 \mathrm{~g}$ of B plant $\mathrm{t}^{-1}(7.8 \mathrm{~kg}$ $\mathrm{ha}^{-1}$ of B), which is almost eight times greater than the dose applied in this study, which supports the statement made above.

At 24 months after planting, the B sources applied at planting at a dose of $1 \mathrm{~kg} \mathrm{ha}^{-1}$ of B were sufficient to significantly reduce the percentage of plants with bifurcations by approximately $12 \%$ and $14 \%$ for applications of boric acid and borogran, respectively, when compared with the control (Table 6). Maffeis et al. (2000) also observed, in experiments with Eucalyptus citriodora, that the absence of B resulted in the death of the apical bud, with subsequent sprouting of axillary buds. 
With respect to the two foliar applications performed at four and ten months after planting, there was a significant decrease of $14 \%$ in bifurcation of the trees (Table 6). José et al. (2009) report that foliar B application in eucalyptus, using boric acid as a source, may be an alternative to rapid recovery of plants with symptoms of B deficiency. Those same authors state that foliar application of B can be a useful strategy, especially during the dry season because absorption of the element by the root occurs with less intensity due to drought.

Table 6. Percentage of bifurcated trees at 24 months after planting and following boron treatment. Três Lagoas, Mato Grosso do Sul, Brazil, 2014.

\begin{tabular}{cc}
\hline Treatments & \% of bifurcated trees \\
\hline Planting (P) & 22.51 \\
Control & 10.00 \\
Boric acid & 8.31 \\
Borogran & 11.88 \\
\hline DMS & 6.41 \\
\hline Foliar (F) & 20.83 \\
With & 8.00 \\
Without & $5.45^{*}$ \\
\hline DMS & $14.17^{* *}$ \\
Test F & $7.22^{* *}$ \\
P & 31.47 \\
F & 13.62 \\
P x F & \\
\hline C.V. $(\%)$ & \\
General mean &
\end{tabular}

*; ** - not significant; significant by the $\mathrm{F}$ test, at $5 \%$ and $1 \%$ probability.

A significant interaction effect was found at 24 months after planting between the B sources applied at planting regardless whether the micronutrient was applied to the leaves on the percentage of bifurcated trees, whose breakdown is shown in Table 7. In the absence of foliar application, the B sources applied at planting ensured a significant decrease of bifurcated trees when compared to the control. This reduction is on the order of $28 \%$ and $29 \%$ for boric acid and borogran, respectively. Paula (2009), studying B sources with different solubilities, found that for a dose of $4 \mathrm{~kg} \mathrm{ha}^{-1}$ of B applied in a continuous stream over the canopy projection in soil with medium B content, boric acid was more effective at preventing B deficiency symptoms compared with the less soluble source. That same author states that with the use of the more soluble source, the B requirements in the rainy season when vegetative growth is intense are readily met. In this study, no difference was observed between sources.

When B was omitted at planting, the two foliar B applications were sufficient to decrease the percentage of trees with symptoms of B deficiency, exhibiting a $35 \%$ reduction in bifurcated trees compared to treatments without foliar application of the element. There was a negative correlation ( $\mathrm{r}$ $=-0.85^{* *}$ ) between the leaf $\mathrm{B}$ concentration and the percentage of bifurcated trees. Sgarbi et al. (1999) report, in E. grandis x E. urophylla clones, a 35\% reduction in the incidence of dieback in sandy soils and $45 \%$ in clayey soils with application of $2.2 \mathrm{~kg}$ $\mathrm{ha}^{-1}$ of $\mathrm{B}$ in the Três Marias region, Minas Gerais, Brazil, an area characterised by long periods of drought during the year. 
Table 7. Breakdown of the interaction between boron application at planting and foliar application on the percentage of bifurcated plants at 24 months after planting. Três Lagoas, Mato Grosso do Sul, Brazil, 2014.

\begin{tabular}{clll}
\hline \multirow{2}{*}{ Planting } & & Foliar & \\
\cline { 2 - 4 } & With & & Without \\
\hline Control & $5.02 \mathrm{a} \mathrm{B}$ & & $40.00 \mathrm{a} \mathrm{A}$ \\
Boric acid & $8.34 \mathrm{a}$ & & $11.66 \mathrm{~b}$ \\
Borogran & $5.86 \mathrm{a}$ & & $10.82 \mathrm{~b}$ \\
\hline DMS $_{(\mathrm{P})}$ & & 16.79 & \\
DMS $_{(\mathrm{F})}$ & & 13.84 & \\
\hline
\end{tabular}

Means followed by different lowercase letters in columns and capital letter in lines differ by Tukey test to a level of $1 \%$ probability.

Neither the sources of B applied at planting nor foliar B application influenced the foliar concentrations of macronutrients at 24 months after planting (Table 8). According to the ranges deemed adequate by Dell et al. (2001), foliar concentrations of macronutrients are within the adequate ranges, except for foliar $\mathrm{K}$, which is slightly below the range considered adequate. These ranges are as follows: $\mathrm{N}$, from 18 to $30 \mathrm{~g} \mathrm{~kg}^{-1} ; \mathrm{P}$, from 1 to $3 \mathrm{~g} \mathrm{~kg}^{-1} ; \mathrm{K}$, from 6 to $18 \mathrm{~g} \mathrm{~kg}^{-1}$; $\mathrm{Ca}$, from 3 to $8 \mathrm{~g} \mathrm{~kg}^{-1} ; \mathrm{Mg}$, from 1 to $3 \mathrm{~g} \mathrm{~kg}^{-1}$; and $\mathrm{S}$, from 1.5 to $3 \mathrm{~g} \mathrm{~kg}^{-1}$. Even with low $\mathrm{K}$ concentration, no nutrient deficiency symptoms were observed in the crop.

The B sources applied at planting significantly influenced leaf concentrations of $\mathrm{Mn}$ at 24 months after planting (Table 9). Borogran fertilizer application resulted in greater $\mathrm{Mn}$ accumulation in the leaf compared with the absence of B application; however, Mn accumulation did not differ from treatments subjected to application of boric acid to the plant. This observation is difficult to explain because borogran does not affect soil reaction in the amount used.

The B sources applied at planting did not significantly influence the leaf concentrations of the element at 24 months after planting, i.e., it is possible that higher doses are needed for the studied clone due to the high bifurcation rate in the treatments without B application, although these leaf concentrations exceed those deemed adequate by Dell et al. (2001). These results are in agreement with those obtained by Ferrando and Zamalvide (2012), who reported in a study performed in Uruguay that sources of B with different solubilities applied at planting did not significantly influence the foliar concentrations of the element, i.e., both the medium and high solubility sources provided good availability of $\mathrm{B}$ to the eucalyptus trees because the leaf $\mathrm{B}$ concentrations were within the range considered adequate for the species studied. 
Table 8. Macronutrient concentrations in eucalyptus leaves at 24 months after planting and following boron treatment. Três Lagoas, Mato Grosso do Sul, Brazil, 2014.

\begin{tabular}{|c|c|c|c|c|c|c|}
\hline \multirow{2}{*}{ Treatments } & $\mathrm{N}$ & $\mathrm{P}$ & $\mathrm{K}$ & $\mathrm{Ca}$ & $\mathrm{Mg}$ & $\mathrm{S}$ \\
\hline & \multicolumn{6}{|c|}{$\mathrm{g} \mathrm{kg}^{-1}$} \\
\hline \multicolumn{7}{|l|}{ Planting (P) } \\
\hline Control & $18.78 \mathrm{a}$ & $1.17 \mathrm{a}$ & $5.33 \mathrm{a}$ & $6.15 \mathrm{a}$ & $1.92 \mathrm{a}$ & $1.54 \mathrm{a}$ \\
\hline Boric acid & $19.23 \mathrm{a}$ & $1.19 \mathrm{a}$ & $5.67 \mathrm{a}$ & $5.99 \mathrm{a}$ & $1.91 \mathrm{a}$ & $1.50 \mathrm{a}$ \\
\hline Borogran & $18.85 \mathrm{a}$ & $1.13 \mathrm{a}$ & $5.33 \mathrm{a}$ & $5.69 \mathrm{a}$ & $1.79 \mathrm{a}$ & $1.50 \mathrm{a}$ \\
\hline DMS & 0.64 & 0.13 & 1.38 & 1.07 & 0.33 & 0.11 \\
\hline \multicolumn{7}{|l|}{ Foliar (F) } \\
\hline With & $19.16 \mathrm{a}$ & $1.15 \mathrm{a}$ & $5.56 \mathrm{a}$ & $5.86 \mathrm{a}$ & $1.85 \mathrm{a}$ & $1.49 \mathrm{a}$ \\
\hline without & $18.75 \mathrm{a}$ & $1.17 \mathrm{a}$ & $5.33 \mathrm{a}$ & $6.03 \mathrm{a}$ & $1.90 \mathrm{a}$ & $1.53 \mathrm{a}$ \\
\hline DMS & 0.43 & 0.09 & 0.91 & 0.71 & 0.22 & 0.07 \\
\hline \multicolumn{7}{|l|}{ Test $\mathrm{F}$} \\
\hline $\mathrm{P}$ & $2.19^{\mathrm{ns}}$ & $0.78^{\mathrm{ns}}$ & $0.29^{\mathrm{ns}}$ & $0.73^{\mathrm{ns}}$ & $0.81^{\mathrm{ns}}$ & $0.88^{\text {ns }}$ \\
\hline $\mathrm{F}$ & $4.48^{\mathrm{ns}}$ & $0.40^{\mathrm{ns}}$ & $0.29^{\mathrm{ns}}$ & $0.30^{\mathrm{ns}}$ & $0.21^{\mathrm{ns}}$ & $1.84^{\mathrm{ns}}$ \\
\hline $\mathrm{P} \times \mathrm{F}$ & $6.57^{\mathrm{ns}}$ & $0.83^{\text {ns }}$ & $2.06^{\mathrm{ns}}$ & $0.17^{\mathrm{ns}}$ & $1.09^{\mathrm{ns}}$ & $0.33^{\text {ns }}$ \\
\hline C.V. $(\%)$ & 2.91 & 7.07 & 15.97 & 11.41 & 10.96 & 4.49 \\
\hline General mean & 18.95 & 1.16 & 5.44 & 5.94 & 1.87 & 1.51 \\
\hline
\end{tabular}

ns - not significant by the $\mathrm{F}$ test, at $5 \%$ probability.

Means followed by the same letter in the column do not differ by Tukey test at $5 \%$ probability.

Table 9. Micronutrient concentrations in eucalyptus leaves at 24 months after planting and following boron treatment. Três Lagoas, Mato Grosso do Sul, Brazil, 2014.

\begin{tabular}{cccccc}
\hline \multirow{2}{*}{ Treatments } & $\mathrm{B}$ & $\mathrm{Cu}$ & $\mathrm{Fe}$ & $\mathrm{Mn}$ & $\mathrm{Zn}$ \\
\cline { 2 - 5 } & & & $\mathrm{mg} \mathrm{kg}$ & \\
\hline Planting (P) & & & & \\
Control & $31.02 \mathrm{a}$ & $10.33 \mathrm{a}$ & $176.00 \mathrm{a}$ & $777.50 \mathrm{~b}$ & $9.33 \mathrm{a}$ \\
Boric acid & $32.24 \mathrm{a}$ & $8.00 \mathrm{a}$ & $138.17 \mathrm{a}$ & $792.17 \mathrm{ab}$ & $9.00 \mathrm{a}$ \\
Borogran & $32.72 \mathrm{a}$ & $7.67 \mathrm{a}$ & $130.67 \mathrm{a}$ & $934.50 \mathrm{a}$ & $8.00 \mathrm{a}$ \\
\hline DMS & 7.76 & 4.81 & 89.75 & 151.40 & 1.68 \\
\hline Foliar (F) & & & & \\
With & $35.19 \mathrm{a}$ & $7.56 \mathrm{a}$ & $128.11 \mathrm{a}$ & $876.78 \mathrm{a}$ & $8.56 \mathrm{a}$ \\
Without & $28.79 \mathrm{~b}$ & $9.78 \mathrm{a}$ & $168.44 \mathrm{a}$ & $792.67 \mathrm{a}$ & $9.00 \mathrm{a}$ \\
\hdashline DMS & 5.15 & 3.19 & 59.53 & 100.42 & 1.11 \\
\hline Test F & & & & \\
P & $0.19^{\text {ns }}$ & $1.37^{\text {ns }}$ & $1.10^{\text {ns }}$ & $4.94^{*}$ & $2.57^{\text {ns }}$ \\
F & $7.65^{*}$ & $2.41^{\text {ns }}$ & $2.28^{\text {ns }}$ & $3.48^{\text {ns }}$ & $0.79^{\text {ns }}$ \\
P x F & $0.39^{\text {ns }}$ & $6.81^{\text {ns }}$ & $1.34^{\text {ns }}$ & $1.00^{\text {ns }}$ & $3.17^{\text {ns }}$ \\
\hline C.V. $(\%)$ & 15.33 & 35.06 & 38.22 & 11.45 & 12.07 \\
General mean & 31.99 & 8.67 & 148.28 & 834.72 & 8.78 \\
\hline
\end{tabular}

$\mathrm{ns} ;{ }^{*}$ - not significant and significant by the $\mathrm{F}$ test, at $5 \%$ probability.

Means followed by the same letter in the column do not differ by Tukey test at $5 \%$ probability. 
Foliar applications of B significantly influenced the leaf concentrations of the element at 24 months after planting; however, this effect did not translate into increases in height, DBH or timber volume. However, a positive correlation was observed ( $\mathrm{r}$ $=0.77^{* *}$ ) between the leaf concentration of $\mathrm{B}$ and plant height.

According to Dell et al. (2001), the mean concentrations of $\mathrm{B}$ and $\mathrm{Fe}$ are above the range considered adequate, whereas the $\mathrm{Zn}$ concentration is below the recommended range, and $\mathrm{Mn}$ and $\mathrm{Cu}$ were in the proper range, which for B are from 15 to 27 , for $\mathrm{Cu}$ are from 2 to 11 , for $\mathrm{Zn}$ are from 15 to 50, for $\mathrm{Mn}$ are from 60 to 2300 and for Fe are from 25 to $130 \mathrm{mg} \mathrm{kg}^{-1}$.

Considering that the leaf $\mathrm{B}$ concentrations are above those considered adequate even in treatments with no B application, the decrease in the bifurcation index with application of B suggests that for this index, the leaf $\mathrm{B}$ concentration is not a parameter indicative of this evaluation, according to the relevant citations.

\section{Conclusions}

At 21 months after planting, the B sources were similar with respect to plant height. Simultaneously, considering non-application of the nutrient to the soil, plant height responded positively to foliar B application.

Both the application of the B at planting, regardless of the source used, and foliar application of the element were sufficient to decrease symptoms of B deficiency, reducing tree bifurcation.

At 24 months after planting, there was an increase in the leaf B concentration with foliar B application; however, there was no improvement in growth, DBH or timber volume.

\section{Aknowlegment}

To Fundação de Amparo à Pesquisa do Estado de São Paulo (FAPESP) and to Cargill Agrícola S/A TO FINANCIAL SUPPIORT. (Processo FAPESP: 2012/05593-7 e 2014/03387-6).

\section{References}

ASSOCIAÇÃO BRASILEIRA DE PRODUTORES DE FLORESTAS PLANTADAS - ABRAF. Anuário Estatístico da ABRAF - ano base 2009. Brasília: ABRAF, 2010. $140 \mathrm{p}$.

. Anuário Estatístico da ABRAF - ano base 2012. Brasília: ABRAF, 2013. 148 p.

BARRETTO, V. C. M.; VALERI, S. V.; SILVEIRA, R. L. V.; TAKAHASHI, E. N. Eficiência de uso de boro no crescimento de clones de eucalipto em vasos. Scientia Forestalis, Piracicaba, n. 76, p. 21-33. 2007.

BARROS, N. F. Interpretação de análises químicas de solo para o crescimento de Eucalyptus spp. Revista Árvore, Viçosa, MG, v. 6, n. 1, p. 38-44, 1982.

BARROS, N. F.; NOVAIS, R. F. Eucalypt nutrition and fertilizer regimes in Brazil. In: ATTIWILL, P. M.; ADAMS, M. A. Nutrition of the eucalypts. Melbourne: CSIRO, 1996. p. 335-356.

BOUCHARDET, J. A. Crescimento, características fisicas e anatômicas da madeira juvenil de dois clones de Eucalyptus grandis Hill ex Maiden em resposta à aplicação de boro. 2002. Dissertação (Mestrado em Recursos Florestais) - Escola Superior de Agricultura Luiz de Queiroz. Universidade de São Paulo, Piracicaba.

BROWN, P. H; BELLALOUI, N.; WIMMER, M. A.; BASSIL, E. S.; RUIZ, J.; HU, H.; PFERFFER, H.; DANNEL, F.; ROMHELD, V. Boron in plant biology. Plant Biology, Stuttgart, v. 4, n. 2, p. 205-223, 2002.

CAMPOS, J. C. C.; LEITE, H. G. Mensuração florestal: perguntas e respostas. Viçosa: Editora UFV, 2002. 407 p.

COUTINHO, J.; BENTO, J.; VALE, R. Efeito da aplicação do boro em povoamentos de Eucalyptus globulus no norte e no centro de Portugal. $2^{\circ}$ Relatório intercalar do projeto de investigação de CEDR. Vila Real: UTAD, 1995. 32 p.

DAHMARDEH, M.; MEHRAVARAN, L.; NADERI, S. Eucalyptus plantlet growth in relation to foliar application with complete fertilizers in Southeast of Iran. African Journal of Biotechnology, Grahamstown, v. 10, n. 66, p. 14812-14815, 2011. 
DELL, B.; MALAJCZUK, D.; XU, D.; GROVE, T. S. Nutrient disorders in plantation eucalypts. $2^{\text {th }}$ ed. Camberra: ACIAR, 2001. 188 p.

EMPRESA BRASILEIRA DE PESQUISA AGROPECUÁRIA - EMBRAPA. Sistema brasileiro de classificação de solos. 3. ed. revisada. Brasília: Editora, 2013. 353 p.

EPSTEIN, E.; BLOOM, A. J. Mineral nutrition of plants: principles and perspectives. Sunderland: Sinauer Associates, 2006. 400 p.

FAQUIN, V. Nutrição mineral de plantas. Lavras: UFLA/FAEPE, 2005. 183 p.

FERRANDO, M. G.; ZAMALVIDE, J. P. Aplicación de boro en eucalipto: comparación de fuentes. Revista Árvore, Viçosa, MG, v. 36, n. 6, p. 1191-1197, 2012.

FERREIRA, D. F. SISVAR: um programa para análises e ensino de estatística. Revista Symposium, Lavras, v. 6 , n. 1, p. 36-41, 2008.

FONSECA, S.; MALUF, J. L. P.; OLIVEIRA, A. C. Adubação de Eucalyptus camaldulensis com boro e zinco em solos de cerrado na região de Brasilândia-Minas Gerais. In: CONGRESSO FLORESTAL BRASILEIRO, 6., Campos do Jordão. Anais... São Paulo: SBS; SBEF, 1990. v. 3, p. 403-406.

GUPTA, U. C. Factors affecting boron uptake by plants. In:__. (Ed.). Boron and its role in crop production. Boca Raton: Crc Press, 1993. cap. 5, p. 87-104.

GUPTA, U. C.; JAME, Y. M.; CAMBELL, C. A.; LEYSHON, A. J.; NICHOLAICHUK, W. Boron toxicity and deficiency: a review. Canadian Journal of Soil Science, Ottawa, v. 65, n. 3, p. 381-409, 1985.

JOSÉ, J. F. B. de S.; SILVA, I. R.; BARROS, N. F.; NOVAIS, R. F.; SILVA, E. F.; SMYTH, T. J.; LEITE, F. P.; NUNES, F. N.; GEBRIM, F. O. Boron mobility in eucalyptus clones. Revista Brasileira de Ciência do Solo, Viçosa, MG, v. 33, n. 6, p. 1733-1744, 2009.

LOPES, A. S. Micronutrientes: filosofias de aplicação, fontes, eficiência agronômica e preparo de fertilizantes. In: SIMPÓSIO SOBRE MICRONUTRIENTES NA AGRICULTURA, 1988, Jaboticabal. Anais... Piracicaba: POTAFOS/CNPQ, 1991. p. 357-390.

MAFFEIS, A. R.; SILVEIRA, R. L. V. A.; BRITO, J. O. Reflexos das deficiências de macronutrientes e boro no crescimento de plantas, produção e qualidade de óleo essencial em Eucalyptus citriodora. Scientia Forestalis, Piracicaba, n. 57, p. 87-98, 2000.

MALAVOLTA, E. Elementos de nutrição mineral de plantas. São Paulo: Editora Agronômica Ceres, 1980. $251 \mathrm{p}$.
MALAVOLTA, E.; VITTI, G. C.; OLIVEIRA, S. A. Avaliação do estado nutricional das plantas: princípios e aplicações. 2. ed. Piracicaba: Associação Brasileira para a Pesquisa da Potassa e do Fosfato, 1997. 319 p.

MARSCHNER, H. Mineral nutrition of higher plants. London: Academic, 1995. 889 p.

MARTINS, L. F. da S.; POGGIANI, F.; OLIVEIRA, R. F. de; GUEDES, M. C.; GONÇALVES, J. L. de M. Características do sistema radicular das árvores de Eucalyptus grandis em resposta à aplicação de doses crescentes de biossólido. Scientia Forestalis, Piracicaba, n. 65 , p. 207-218, 2004.

MATTIELlO, E. M.; RUIZ, H. A.; SILVA, I. R. da; GUERRA, P. de C.; ANDRADE, V. M, de; Características fisiológicas e crescimento de clones de eucalipto em resposta ao boro. Revista Árvore, Viçosa, MG, v. 33, n. 5, p. 821-830, 2009.

NOVAIS, R. F.; BARROS, N. F.; NEVES, J. C. L. Nutrição mineral do eucalipto. In: BARROS, N. F.; NOVAIS, R. F. (Ed.). Relação solo-eucalipto. Viçosa: Folha de Viçosa, MG, 1990. p. 133-189.

NOVELINO, J. O.; NEVES, J. C. L.; BARROS, N. F.; NOVAIS, R. F.; MUNIZ, A. S. Efeito de níveis em solução nutritiva no crescimento de mudas de Eucalyptus spp. Revista Árvore, Viçosa, MG, v. 6, n. 1, p. 45-51, 1982.

OLIVEIRA, S. A.; MORAES, M. L. T.; BUZETTI, S. Efeito da adubação NPK com e sem boro no crescimento de Eucalyptus citriodora Hook. Revista do Instituto Florestal, São Paulo, v. 13, n. 2, p. 115-120, 2001.

PAULA, T. A. Doses, fontes e formas de aplicação de boro em floresta de eucalipto. 2009. Dissertação (Mestrado em Fitotecnia) - Escola Superior de Agricultura Luiz de Queiroz, Universidade de São Paulo, Piracicaba.

PAVAN, B. E. Crescimento de clones de eucalipto submetidos a diferentes regimes hídricos em casa de vegetação. 2003. Monografia (Trabalho de Graduação de Curso em Agronomia) - Faculdade de Ciências Agrárias e Veterinárias, Universidade estadual Paulista, Jaboticabal.

PINHEIRO, A. L. Reflexos da fertilização mineral de boro na estrutura anatômica, no crescimento e na secade-ponteiro de Eucalyptus citriodora Hook e Eucalyptus camaldulensis Dehn no Cerrado de Minas Gerais. 1999. Tese (Doutorado em Ciências Florestais) - Universidade Federal do Paraná, Curitiba.

RAIJ, B. van; ANDRADE, J. C.; CANTARELLA, H.; QUAGGIO, J. A. Análise química para avaliação da fertilidade de solos tropicais. Campinas: IAC, 2001. 285 p. 
RAIJ, B. van; CANTARELLA, H.; QUAGGIO, J. A.; FURLANI, A. M. C. Recomendações de adubação e calagem para o estado de São Paulo. 2. ed. Campinas: IAC, 1997. 285 p. (Boletim técnico, 100).

REGUERA, M.; ESPI, A.; BOLANOS, L.; BONILLA, I.; REDONDO NIETO, M. Endoreduplication before cell differentiation fails in boron-dificent legume nodules. Is boron involved in signaling during cell cycle regulation? New Phytologist, Cambridge, v. 183, n. 1, p. 8-12, 2009.

ROCHA, G. N.; GONÇALVES, J. L. M.; MOURA, I. M. Mudanças da fertilidade do solo e crescimento de um povoamento de Eucalyptus grandis fertilizado com biossólido. Revista Brasileira de Ciência do Solo, Viçosa, MG, v. 28, n. 4, p. 623-639, 2004.

SANCHEZ, P. A. Suelos del trópicos. San José: IICA, $1981.634 \mathrm{p}$.

SGARBI, F.; SILVEIRA, R. L. V. A.; TAKAHASHI, E. N.; CAMARGO, M. A. F. Crescimento e produção de biomassa de clone de Eucalyptus grandis $x$ Eucalyptus urophylla em condições de deficiência de macronutrientes, B e Zn. Scientia Forestalis, Piracicaba, n. 56, p. 69-82, 1999.

SILVEIRA, R. L. V. A.; HIGASHI, E. N.; SGARBI, F.; MUNIZ, M. R. A. Seja doutor do seu eucalipto. Informações Agronômicas, Piracicaba, n. 93, p. 1-31, 2001.
SILVEIRA, R. L. V. A.; MOREIRA, A.; TAKAHASHI, E. N.; SGARBI, F.; BRANCO, E. F. Sintomas de deficiência de macronutrientes e de boro em clones híbridos de Eucalyptus grandis com Eucalyptus urophylla. Cerne, Lavras, v. 8, n. 2, p. 108-117, 2002.

SILVEIRA, R. L. V. A.; TAKAHASHI, E. N.; SGARBI, F.; CAMARGO, M. A. F.; MOREIRA, A. Crescimento e estado nutricional de brotações de Eucalyptus citriodora sob doses de boro em solução nutritiva. Scientia Forestalis, Piracicaba, n. 57, p. 53-67, 2000.

STEINER, F.; LANA, M. C.; ZOZ, T.; FEY, R.; FRANDOLOSO, J. F. Boron adsorption in lowland soils from Paraná State, Brazil. Semina: Ciências Agrárias, Londrina, v. 33, n. 4, p. 1391-1402, 2012.

TIRLONI, C.; DANIEL, O.; VITORINO, A. C. T.; NOVELINO, J. O.; CARDUCCI, C. E.; HEID, D. M. Crescimento de Corymbia citriodora sob aplicação de boro nas épocas secas e chuvosas no Mato Grosso do Sul, Brasil. Silva Lusitana, Oeiras, v. 19, n. 2, p. $185-$ 194, 2011.

VANDERLEI, J. C.; FAQUIN, V.; GUEDES, G. A. A.; CURI, N. Boro em materiais de três solos do município de Lavras, MG. Pesquisa Agropecuária Brasileira, Brasília, v. 23, n. 12, p. 1421-1430, 1988.

VOLKWEISS, S. J. Fontes e métodos de aplicação. In: FERREIRA, M. E.; CRUZ, M. C. P. da (Ed.). Micronutrientes na agricultura. Piracicaba: Potafos, 1991. p. 391-412. 
